\title{
The Program of All-Inclusive Care for the Elderly (PACE): The Innovative and Economically Viable Model of American Geriatric Care
}

\author{
Program Kompleksowej Opieki Geriatrycznej (PACE): Innowacyjny i ekonomiczny model \\ amerykańskiej opieki geriatrycznej
}

\section{Urszula Polska}

Mercy LIFE of Alabama

CORRESPONDING AUTHOR/AUTOR DO KORESPONDENCJ:

Urszula Polska

2900 Spring Hill Ave., Mobile, AL, 36607, USA

tel. +1-251-287-8478

e-mail:UrszulaP@mercylifeal.com

\section{AMERYKAN'SKIEJ OPIEKI GERIATRYCZNE}

Streszczenie. Celem pracy jest przedstawienie nowoczesnego modelu pozainstytucjonalnej opieki geriatrycznej, który działa w Stanach Zjednoczonych pod nazwą Program Kompleksowej Opieki Geriatrycznej (PACE-Program of All-Inclusive Care for the Elderly). Konsekwencje ekonomiczne starzejącego się społeczeństwa z wieloma chorobami przewlekłymi stwarzają potrzebę nowych rozwiązań w dostarczaniu opieki medycznej. Autorka na podstawie wnikliwego przeglądu dostępnej literatury na temat programów PACE oraz własnego doświadczenia z pracy przedstawia historię programu, jego złożony charakter i funkcjonalność z uwzględnieniem korzyści społecznych i gospodarczych. W artykule ujawnione są trudności i ograniczenia w funkcjonowaniu programów. Poza tym praca dodatkowo przedstawia różnorodne rozwiązania, które pozwoliłyby na zastosowanie i popularyzację programu na skalę międzynarodową.

Autorka, pracuje w Mercy LIFE, Alabama, PACE programie w charakterze pielęgniarki ANP, zapewniając swoim pacjentom podstawową opiekę ambulatoryjną. Autorka uwzględniła potrzebę stworzenia podobnego modelu do PACE na terenie własnej 0jczyzny, Polski, gdzie wartości i normy kulturowo-społeczne obywateli dotyczące opieki nad ich bliskimi członkami rodziny preferują jako standard opiekę poza instytucjonalną w środowisku domowym pacjenta przy udziale rodziny.

Autorka stwierdza, że model podobny do PACE byłby optymalnym modelem opieki geriatrycznej w krajach wysoko rozwiniętych poza USA, które doświadczają wzrostu demograficznego populacji w tej grupie. Wyżej wymieniona fluktuacja demograficzna jest charakterystyczna dla XXI wieku i w opinii autora stan ten jest wyznacznikiem bezzwłocznego działania w celu zapobiegania jej skutkom ekonomicznym.

Słowa kluczowe: opieka geriatryczna, Program Kompleksowej Opieki Geriatrycznej (PACE)

\section{THE PROGRAM OF ALL-INCLUSIVE CARE FOR THE ELDERLY (PACE): THE INNOVATIVE AND ECONOMICALLY} VIABLE MODEL OF AMERICAN GERIATRIC CARE

Abstract. The aim of this paper is to present a modern model of non-institutional geriatric care which operates in the US, called the Program of All-Inclusive Care for the Elderly (PACE). The economic consequences of an aging population with multiple chronic diseases are creating new solutions in the delivery of medical care. The author of the following article, based on review of PACE literature and her own experience, will focus on the history of the program, its nature, the social and economic advantages, and its efficacy in practice. In addition, the difficulties and limitations of PACE are analyzed, taking into account solutions for increased availability and popularization of the program on an international scale.

Author currently works as an ANP at Mercy LIFE (Living Independently For Elders) of Alabama, a PACE organization, delivering primary care. She has identified a need for a model similar to PACE in the context of her own home country of Poland, where cultural and societal norms value caring for a loved one in his or her own household rather than institutional care.

The author concludes that the PACE model would be indispensable as a geriatric healthcare model for countries outside the US experiencing a rapid growth in elderly patients resulting from demographic shifts common in the $21^{\text {st }}$ century. Fast response is needed in creation of a similar program to PACE to prevent future economical consequences affecting medical care for the elderly. 


\section{INTRODUCTION}

\section{The Demographic Effects of an Aging Population on the Health Budget}

In the ever-changing landscape of public healthcare, an increasing human population creates new challenges in the geriatric healthcare system. Approximately $20 \%$ of the US population constitutes of individuals 65 years of age and older, what represents more than 43 million people. According to the US Bureau of Statistics from 2012, this figure is to double by 2050 [1-3]. It is estimated that $5 \%$ of the population over the age of 65 consumes $50 \%$ of all costs incurred for health care [1]. This cost is directly proportional to age, severity of patients' health, and their complex care needs. Medicare budget analysis from 2011 showed that those between the ages of 65-70, representing $26 \%$ of the Medicare population consume only $15 \%$ of the total budget for medical expenses. For comparison, a group of octogenarians representing 24\% of Medicare participants consumed up to $33 \%$ of this budget. Care costs increase dramatically over the 90 years of age towards the decline of life and just before death. It is expected that the population growth in the latter group between the years 2010-2050 will increase four-fold [4]. The Medicare and Medicaid budget determines access to health care of every US citizen over 65 years of age. (Medicare is the federal health insurance program designed for people over 65 and for disabled persons under 65 years of age. Medicaid is a state and federal system of free medical care for the poor and those who are in special situations, regardless of age) [5]. The coming years predict an increase in the degree of dependence of an aging population on their families in terms of care and financial support due to the budget deficits of the aforementioned organizations [3]. Among a sample of pensioners, $67 \%$ have an average of two to three chronic diseases, and $24.6 \%$ have four or more such diseases. This degree of health-related problems not only requires the use of additional financial resources, but also encourages the creation of new systems of health care, which would give dependents and their families a chance to balance family life and work. Multiple studies conducted among groups of caregivers have shown increasing rates of absence at work, physical and mental exhaustion and financial costs related to the need to take care of their loved ones [6].

\section{REVIEW}

\section{The History of the Program of All-Inclusive Care for the Elderly (PACE)}

The Program of All-Inclusive Care for the Elderly (PACE) covers the whole complex of non-institutional care for patients and their families. PACE is a model of care that grew out of the initiative of public health in order to promote efficient and effective treatment of patients with multiple chronic diseases in an environment outside of traditional institutional care. PACE takes care of patients who, for health reasons, qualify for life in long-term care facilities, by providing an alternative care system, allowing such patients to continue to live at home in their current social environment $[6,7]$.

The first model of non-institutional care for seniors was created in the US in the early 1970s in the Chinatown district of San Francisco, California [7]. This program was designed to provide daily care to the aging members of the Asian community. In the culture of the Asian community, institutional medical care of a family member was not widely accepted. In addition, financial costs made institutional care less popular [6,7]. On the basis of this model in 1973, a model of care called On Lok was created, which in Cantonese means "peaceful and happy abode." The program provided additional medical services, social rehabilitation and daily care [7-9]. In the following years, the program underwent extension and included the provision of food, transport and services at home. Day care centers for adults quickly proved to be successful because of their flexibility in meeting the needs of the elderly. In 1979, the program received a four-year grant from the Department of Health and Human Services for development of this model. In 1990, the PACE model received financial assistance from the Centers for the Medicare \& Medicaid Services (CMS) to develop and operate the program. Both Medicare (the federal health insurance program for the elderly) and Medicaid (a federal program based on the needs of people in special situations) programs help to decrease the medical costs [5].

It was only in later years, under the Budget Act of 1997, that Congress formally recognized PACE as a high-quality model in providing comprehensive geriatric care to retirees and licensed PACE to obtain reimbursement for the care exercised by CMS. The legal basis for the payments for the care and operation of the PACE model since the implementation of the act is strictly defined by the CMS [7-10]. The evolution of the PACE model has continued over the last 30 years, although the principle of care and the challenges remained the same [8]. Over these years, centers for comprehensive daily care similar to PACE have been opened in other states in the US [6]. In 2015 the National PACE Association (NPA) recorded the existence of 116 such programs operating within 32 US states [7].

The contemporary model of PACE is a non-institutional care for patients over the age of 55 who, for medical reasons, are eligible for life in a nursing home. The program gives participants the possibility to continue living at home and participate in family life, as well as enable caregivers to continue their careers $[3,6,8-14]$. PACE program provides patients with prevention, primary care, dental care and treatment of acute and chronic diseases in the daily care center and in the patient's environment. The program also covers the costs of laboratory and diagnostic testing. It provides participants with physical therapy, occupational therapy, medical transport, meals, medications and dietary consultations [3,6,8-13]. When a patient requires hospitalization, PACE cooperates with the hospital and covers the total costs. In situations of deteriorating health of the patient, the PACE model provides care in nursing homes for short or long-term durations. In addition, each patient has an individual care plan which is evaluated by an interdisciplinary team every six 
months (or more frequently if there has been a sudden change in health or family circumstances). Decisions concerning the care of PACE program participants on all issues and at all levels are taken collectively during the interdisciplinary team's daily sessions. The program also takes into account support for care takers and their families by offering respite care for the relief of the physical and mental health of the family $[6,8-10,13,14]$. The PACE program is mostly required to pay for medical care of its patients, however, in certain situations PACE additionally covers the cost of services that would improve safety, health and functionality of the patient. The program provides a 24/7 telephone service for the participants needing advice or in case of emergency [14].

The PACE organizational structure includes an interdisciplinary team (IDT), an adult day care center and a health clinic. The PACE interdisciplinary team jointly makes decisions about every aspect of the patient's life, taking into account his/her health, psychological, and environmental needs. This team exists in order to effectively and efficiently solve health problems of patients as soon as possible to prevent medical complications. The opinions of the IDT are based on the comprehensive analysis of the patient's status and his/her environment. They become the basis for a diagnosis and then, the team chooses the best decision for its implementation. Decisions are made collectively in the form of discussion and vote. Team members apply the principles of professional ethics maintaining the patient's dignity $[6,14,15]$. The IDT consists of an administrator, doctor - medical director, advanced nurse practitioners, registered nurses, nursing aids, a nutritionist, a home care coordinator, a director of adult day care center, social workers, a physiotherapist, a coordinator of recreational activities and occupational therapy and a transport representative [6,8,13-15]. A clergy member is also included in the IDT, as Mercy LIFE of Alabama is a Catholic-faith institution. At the program of Mercy LIFE of Alabama, the IDT meets every morning in the conference room. Issues raised during these meetings concern reports from night shifts and from visits at hospitals or long-term care homes. The team debates on the current issues of each patient resulting from changes in his/her current health, social or financial situation. A frequent issue that accompanies discussion is ensuring the safety of the participants, aiming at prevention of falls and unnecessary hospitalizations. Proposed solutions in this regard may relate to small repairs or construction of safe ramps for wheelchairs. During the daily session, patients' requests are evaluated, which may concern orthopedic equipment, dental prostheses, hearing aids or types of services, like housekeeping, laundry, etc. Any grievances and requests from participants or caregivers concerning patient care are taken into account and the interdisciplinary team makes decisions and formal responses regarding these issues daily. The PACE program has guidelines how to handle above issues in a timely manner which are strictly defined by CMS with accordance to the Code of Federal Regulations [15]. The inclusion of those regulations result in the overall satisfaction of participants $[15,16]$. The system of group problem solving and decision making has many positive qualities: it provides the IDT with more options and increases creativity of decisions, provides better economic results, reduces the risk of human error and contributes to more productive time management. All of these qualities are crucial, as PACE does not receive financial returns for all services provided to patients. The PACE program takes full financial responsibility for the taken decisions and their risks. Thus, profits generated by the organizations are the result of optimal decisions $[6,8,14]$. The PACE program has no obligation to pay for services that were not approved by the interdisciplinary team unless the urgency of a situation requires such an undertaking. The PACE model includes a team of staff members responsible for budgeting and marketing [14].

Each PACE program includes a day care center where patients socialize and benefit from recreational therapy. Physical-therapy and occupational therapy are also provided to improve patient safety, mobility and to maintain his/her functionality. According to a nationwide study, each PACE participant spends on average 2-3 days per week at the center depending on their needs [7]. At Mercy LIFE of Alabama, participants spend on average 2 days per week at the center. The arrival of participants in the center allows the team to monitor patients and detect changes in their health status early on $[13,16]$. Workers in the PACE program are required to report alarming changes in health of a patient to the medical center.

The medical clinic is a part of the PACE model. Medical clinic employees provide prevention and primary medical care in the field of acute and chronic diseases. As part of the CMS regulations, PACE is obliged to comply with a strictly specified number of clinical visits over a specified period of time [15]. The patient must be seen in the clinic by MD/ANP for a comprehensive initial assessment, evaluating if they qualify for PACE based on PACE enrollment criteria and CMS regulations. Next, there is a first post-enrollment clinic visit, followed by mandatory visits every 6 months in the form of semiannual and annual comprehensive assessment in order to verify an individual care plan. More frequent visits can occur in the case of sporadic sickness or acute changes in patient's health status $[14,15]$.

PACE has several minibuses adapted to transport people with special needs or disabilities. If hospital treatment is needed, the patients are transported to the hospitals with which the PACE program has signed a contract. PACE also provides transportation for medical consultations with specialists, for diagnostic tests and for visits to the hemodialysis center if needed $[10,11,13,14]$. PACE sources all medications from the central PACE pharmacy.

The agreement included in the PACE program is unlimited in length and cannot be terminated due to deteriorating mental or physical health of the patient. The contract is valid until the patient's death unless the patient himself or his/her caregivers unsubscribe from the program, or the state of his/her health has improved enough so that he no longer meets the eligibility criteria for long-term care. The participant or caregiver may at their own request break the contract without incurring any finan- 
cial liability. The PACE program can break the contract if a participant does not comply with regulations or poses a risk for other members of the program. An examples of PACE regulations violations are when participant brings weapon or abuses some substances during the program. This situation would justify a termination of the patient's contract. The provisions of this procedure are outlined in the CMS regulations for the PACE program [14].

The modern PACE model was created for patients who qualify for institutional care at or above the age of 55 , yet would prefer to stay at home and independently operate under the supervision of the PACE program. The participant must be a resident of the area covered by the PACE program. The patient's health, physical condition and functionality before enrollment cannot constitute a danger to his/her or other patients' safety. The candidate must be able to live safely at home with the assistance of PACE. The participant must agree to abide by all parts of the care contract in the rules of the PACE program to continue $[6,8-10,14,17]$.

\section{Patient Qualification for PACE}

New candidates seeking admission to PACE are subject to a preliminary check by members of the interdisciplinary team regarding the aforementioned constraints and regulations. The team studies the patient's environment, caregiver's support and involvement in care, current health status and medical history. The patient undergoes an initial clinical assessment by a doctor or nurse practitioner to advance in the qualification process. His fitness is further evaluated in the physiotherapy department. A social worker, a representative of home care and a physiotherapist inspect living conditions and functioning of the patient at home. After analysis, the IDT meets to discuss the results of the observation. The participant must meet criteria for long-term care eligibility prior to enrollment in PACE $[14,15]$. In order to qualify for the program, a PACE specific evaluation form has to be completed and sent to CMS for review. Upon acceptance into the program, financial reimbursement from CMS and from the state Medicaid program is issued to PACE organization $[14,18]$.

\section{Participant Payments Under PACE}

Most of the PACE program participants are eligible for both Medicare and Medicaid and are exempt from any personal payment. Patients who do not have Medicaid, are required to pay additional charges in the form of a monthly bonus to the PACE program (code no 460.186) [14]. Participants with only Medicaid are exempt from all fees. Patients who do not have any form of insurance could pay the cost of private care to gain access to the program's benefits [14-19]. Diane Brown, Executive Director at Mercy LIFE of Alabama reported that $99 \%$ participants of Alabama do not pay any additional cost for medical care in PACE program. Private pay exists but is not very common.

\section{Funding Mechanisms for PACE}

The program is mainly funded by Medicare and Medicaid under strict government regulations specified by CMS $[6,8,14]$. Traditional Medicare has two plans: Plan A and Plan B. Medicare Plan A covers institutional care, while Medicare Plan B covers outpatient care, psychiatric care, hemodialysis, medical equipment and certain drugs $[20,21]$. Most drugs, however, are covered under a plan D, which is an optimal but not free benefit under Medicare coverage. Plan D, however, is fully covered by Medicaid and is required from all PACE participants.

Most of Mercy LIFE participants are dual Medicare and Medicaid eligible and do not have to pay for care, as it was reported by Diane Brown. The PACE program may be additionally sponsored by various private and nonprofit organizations [17]. CMS regulations define the criteria and the amount for the monthly payment for each patient within the PACE model $[9,14,19,22]$. Medicare pays a monthly sum according to risk adjustment; however, Medicaid pays a flat and nonnegotiable rate per capita for each participant according to his state of residency. For example in the state of Alabama, Medicaid pays $\$ 3330$ per capita per month to PACE organization as reported by Diane Brown.

In 2008, the risk adjustment model was introduced by CMS to determine the lump-sum payout for health care under the PACE program [19]. In calculating the index of health risks, demographic factors such as age, sex and degree of disability are considered. In the risk adjustment process, the most serious and advanced illnesses are primarily considered, rather than all patient's diseases. For every serious illness considered, the relative cost of spending per year for treatment is factored into the relative risk index. The degree of disability and functional impairment due to the existence of these diseases influences the risk index. Functionality is defined as performance of activities of daily life (ADL), where the six basic activities are defined as: taking a bath, dressing, using the toilet, continence, moving, and eating on your own. The amount of disrupted functions, expressed on a numerical scale from 1-6, has an impact on the risk index. The use of home care services, medical equipment, wheelchairs and oxygen increases the risk index as well. Advanced age increases the health risk and the cost of healthcare as well. The size of the lump-sum monthly payment received by PACE from Medicare and Medicaid is the sum of the individual healthcare costs [19]. At the PACE program of Mercy LIFE of Alabama, the average patient is 80 years old, has an average of 7.9 medical ailments and is limited to an averagely 3 activities of daily life $[3,23]$. Only $4 \%$ of participants of Mercy LIFE of Alabama PACE program reside in nursing homes, as reported by Diane Brown, compared to about $7 \%$ throughout the country [7].

\section{Advantages of PACE}

PACE provides a high quality standard of care to their patients. The PACE program's overall participant satisfaction level is $72 \%$, compared to $55 \%$ for patients living outside the program. Patients of the PACE program remain functional 
longer in respect of basic and complex functions compared to those living outside of the program $[8,24]$. Providing transportation to the center provides participants with independence and flexibility in the choice of day-to-day activities. Medical care is systematic, resulting in longer life and functionality, as well as decreased risk of death. A financial cost outline for the health care of a PACE participant in the first 6 months in the program is as follows: hospitalization costs decreased by $50 \%$, the length of hospital stays decreased from 6 to 2 days, the number of admissions to nursing homes decreased by $60 \%$ and the length of nursing home stays decreased from 22 days to 7 days [24]. Studies have shown that most people over the age of 65 would prefer to die at home or in a hospice: the PACE program gives participants such choice. However, according to current statistics, only $20 \%$ die at their homes or hospice. Approximately $77 \%$ of patients die in institutions, of which $53 \%$ die in intensive care hospitals [25].

\section{Limitations of PACE}

Despite the high popularity and the rising demand for this model of geriatric care, the program has its limitations. Several researchers reviewed the PACE literature and showed that some participants prefer care at their own homes and stay at a day center is not to their advantage. Dissatisfaction also results from the change of an existing doctor or specialist to a PACE contracted doctor or specialist, as the PACE program is obliged to cooperat with doctors and hospitals with which it has contracts to mitigate financial costs. In addition, the PACE model is less accessible to middle class patients who are not eligible for Medicaid and have to pay monthly premium out of their own pocket to PACE organization $[8,10,16,26]$.

\section{Variants of PACE}

In order to overcome some of the limitations of the existing PACE model, dozens of programs across the country have adopted variants of PACE operation model, giving participants a choice of maintaining their current primary care physician and specialists, choice of coming to the day center as needed and the use of services and care at the patient's home as opposed to only at the day center [9]. One of these variants is the Geriatric Assessment and Care of Elders (GRACE) model of the Wisconsin Partnership Program (WPP) $[8,16,27,28]$. All those changes are aimed at further development of the system and increased satisfaction among participants, as well as at the wider availability of integrated care programs. Some of these variants can have applications in countries outside of the United States as well [6]. One model is not able to provide for all the needs of an aging population, thus increasing need for flexibility in the functionality of programs based on the needs and circumstances of the participants is underlined $[9,16,26]$.

\section{CONCLUSIONS}

The author has identified a need for a model similar to PACE in the context of her own home country of Poland, where cultural and societal norms value caring for a loved one in his or her own household rather than institutional care; thus, she believes the aforementioned PACE model or a modified variant would be ideal for non-institutional care with affordable financial costs and high patient and family satisfaction. Poland, similar to the US and other countries in the world, will face similar demographic problems with respect to rising elderly population with similar issues regarding financial limitations in providing socialized medical health. The problem of a demographic shift towards a growing aging population is an extensive and far-reaching one that encompasses all cultures and countries. A rising elderly population places high stress on a society's ability to provide medical healthcare to those in need. This issue is compounded as long-term geriatric healthcare solutions come at high financial costs, thus necessitating a system similar to the PACE model moving forward.

\section{Program Kompleksowej Opieki Geriatrycznej (PACE): Innowacyjny i ekonomiczny model amerykańskiej opieki geriatrycznej}

\section{WPROWADZENIE}

\section{Skutki demograficzne starzejącego się społeczeństwa a budżet zdrowia}

Zwiększająca się populacja ludzi w wieku geriatrycznym kreuje nowe wyzwania w systemie opieki zdrowotnej. Około 20\% populacji USA stanową ludzie w wieku 65 lat i powyżej, co stanowi ponad 43 miliony ludzi. Według Amerykańskiego Biura Statystyki z roku 2012, liczba ta ma ulec podwojeniu w 2050 roku [1-3]. Szacuje się, że 5\% populacji powyżej 65 roku życia zużywa 50\% wszystkich kosztów poniesionych na opiekę zdrowotną w kraju [1]. Koszt ten jest wprost proporcjonalnie uwarunkowany od wieku, ciężkości stanu zdrowia pacjentów i ich złożonych potrzeb opiekuńczych. Analiza budżetowa Medicare $z$ roku 2011 wykazała, że grupa ludzi w przedziale pomiędzy 65-70 rokiem życia reprezentująca $26 \%$ populacji przynależącej do Medicare, zużyła tylko $15 \%$ całego budżetu przeznaczonego na wydatki medyczne. Dla porównania grupa osiemdziesięciolatków stanowiąca $24 \%$ uczestników Medicare wykorzystała ponad dwukrotnie więcej, bo aż 33\%. Koszty opieki drastycznie rosną powyżej 90 roku 
życia i w okresie schyłkowym życia tuż przed śmiercią. Przewiduje się, że wzrost populacji w tej ostatniej grupie pomiędzy latami 2010-2050 zwiększy się czterokrotnie[4]. Dostęp do opieki zdrowotnej każdego obywatela USA po 65 roku życia jest uzależniony od budżetu Medicare i Medicaid. Medicare jest federalnym programem ubezpieczenia zdrowotnego przeznaczonym dla ludzi powyżej 65 roku i dla inwalidów poniżej 65 roku życia. Medicaid jest federalnym i stanowym systemem bezpłatnej opieki medycznej dla ludzi biednych i znajdujących się w szczególnych sytuacjach losowych lub zdrowotnych bez względu na wiek [5]. Na nadchodzące lata przewiduje się wzrost stopnia uzależnienia starzejącej się populacji od ich rodzin pod względem opiekuńczo-finansowym ze względu na deficyt budżetowy wyżej wymienionych organizacji [3]. Wśród grupy emerytów $67 \%$ posiada średnio od dwóch do trzech chorób przewlekłych, $24.6 \%$ posiada cztery i więcej takich chorób. Stopień ich zaawansowania wymaga nie tylko użycia dodatkowych zasobów finansowych, ale też mobilizuje do stworzenia nowych systemów opieki zdrowotnej, które dałyby szanse podopiecznym i ich rodzinom na równowagę pomiędzy życiem rodzinnym i zawodowym. W wielu badaniach przeprowadzonych wśród grupy opiekunów został udowodniony wzrost zachorowań, zwiększenie absencji w pracy, wzrost fizycznego i psychicznego wyczerpania oraz innych finansowych konsekwencji związanych z koniecznością zapewnienia bezpiecznej opieki swoim podopiecznym [6].

\section{WYNIKI}

\section{Historia programu Program of All-Inclusive Care for the Elderly (PACE)}

Program of All-Inclusive Care for the Elderly (PACE) obejmuje całokształt kompleksowej opieki pozainstytucjonalnej nad pacjentami i ich rodzinami. PACE jest modelem opieki, który wyrósł $\mathrm{z}$ inicjatywy zdrowia publicznego w celu promowania skutecznego i efektywnego leczenia pacjentów z wieloma chorobami przewlekłymi w środowisku poza tradycyjną opieką instytucjonalną. PACE obejmuje opieką pacjentów, którzy ze względów zdrowotnych kwalifikacją się do życia w ośrodkach długoterminowej opieki społecznej, jakkolwiek chcą pozostać w domu i żyć w dotychczasowym środowisku społecznym [6,7].

Pierwszy model opieki pozainstytucjonalnej dla emerytów został utworzony w USA w początkach lat siedemdziesiątych na terenie dzielnicy Chińskiej w San Francisco [7]. Program ten miał na celu zapewnić opiekę dzienną nad starzejącą się i schorowaną społecznością azjatycką. W kulturze społeczności azjatyckiej instytucjonalna opieka medyczna członka rodziny nie była akceptowana. Również ze względów finansowych opieka instytucjonalna była mało popularna [6,7]. Na bazie tego modelu w 1973 roku powstał model opieki o nazwie On Lok co w kantońskim języku miało oznaczać „dom spokojnego i szczęśliwego pobytu.” Program zapewniał dodatkowo usługi medyczne, społeczne, rehabilitację i opiekę dzienną [7-9]. W dalszym okresie działalność programu ulegała rozszerzeniu i obejmowała dostarczanie posiłków, trans- portu oraz świadczenie usług domowych. Ośrodki dziennej opieki dla dorosłych szybko okazały się sukcesem ze względu na ich elastyczność w zaspakajaniu potrzeb osób starszych. W 1979 roku program On Lok otrzymał czteroletni grant od Departamentu Zdrowia i Opieki Społecznej na rozwój powyższego modelu. W 1990 roku PACE model uzyskał pomoc finansową na działalność i rozwój programu od Centers for the Medicare \& Medicaid Services (CMS). Obydwa te programy Medicare (federalny program ubezpieczeń zdrowotnych dla osób starszych) i Medicaid (federalny i stanowy program bezpłatnej opieki oparty na potrzebach osób znajdujących się w szczególnych sytuacjach) mają na celu obniżenie kosztów opieki medycznej [5]. Akt Ustawy Budżetowej z roku 1997 przyczynił się do wielu zmian w rozwoju programów PACE. Kongres formalnie uznał PACE jako wysokiej jakości model w udzielaniu kompleksowej opieki geriatrycznej wobec emerytów i uprawnił PACE do uzyskiwania zwrotu kosztów za sprawowaną opiekę przez CMS. Podstawy prawne dotyczące płatności za opiekę i regulamin funkcjonowania modelu PACE od momentu wprowadzenia w życie aktu tej ustawy są ścisłe określone przez Centers for the Medicare \& Medicaid Services (CMS) [7-10]. Rozwój programu PACE i finansowane kosztów za opiekę ulegały ciągłym zmianom na przestrzeni ostatnich 30 lat, jakkolwiek zasady opieki i wyzwania pozostały wciąż te same [8]. Ośrodki kompleksowej opieki dziennej otwierały swoją działalność w innych stanach Ameryki [6]. W 2015 roku Narodowe Zrzeszenie PACE (NPA) zarejestrowało istnienie 116 programów funkcjonujących na obszarze 32 stanów USA [7].

Współczesny model PACE jest pozainstytucjonalną formą opieki dla pacjentów powyżej 55 roku życia, którzy z przyczyn zdrowotnych kwalifikują się do życia w domach opieki społecznej. Program daje możliwość uczestnikom na kontynuowanie życia w domu i środowisku, a ich opiekunom na pełne uczestnictwo w życiu rodzinnym i zawodowym [3,6,8-14]. PACE zapewnia swoim podopiecznym profilaktykę, opiekę podstawową, dentystyczną, leczenie chorób ostrych i przewlekłych w centrum dziennym i w środowisku pacjenta. Program pokrywa koszty badań i testów diagnostycznych. Zapewnia uczestnikom fizykoterapie, terapię zajęciową, transport medyczny, posiłki, leki oraz konsultacje dietetyczne i specjalistyczne [3,6,8-13]. W przypadku kiedy pacjent wymaga hospitalizacji, PACE koordynuje opiekę i pokrywa jej całkowity koszt. W sytuacjach pogarszającego się stanu zdrowia pacjenta PACE zapewnia opiekę dla swoich podopiecznych w domach opiekuńczych na czas krótki lub długoterminowy. Poza tym każdy pacjent ma indywidualny plan opieki, który jest ewaluowany przez zespół interdyscyplinarny (Interdisciplinary Team, IDT) co sześć miesięcy lub częściej, jeżeli nastąpiła nagła zmiana zdrowia czy zmiana sytuacji rodzinnej. Decyzje w sprawie opieki nad uczestnikami programu PACE w każdej kwestii i na każdym szczeblu podejmowane są kolektywnie podczas codziennych obrad zespołu IDT. Program również uwzględnia pomoc dla opiekunów i ich rodzin, oferując swoim pacjentom krótkie pobyty w domach opiekuńczych w celu odbarczania fizycz- 
nego i psychicznego rodziny od opieki $[6,8-10,13,14]$. PACE program jest zobowiązany pokrywać koszty za opiekę medyczną swoich podopiecznych. PACE dodatkowo pokrywa koszty usług, które miałyby na celu ulepszyć zdrowie, bezpieczeństwo i funkcjonalność pacjenta. Program ponadto zapewnia $24 \operatorname{godz} .7 \mathrm{dni}$ w tygodniu serwis telefoniczny dla uczestników programu i ich rodzin, którzy wymagają porad i konsultacji poza godzinami pracy i w nagłych przypadkach [14].

Struktura organizacyjna PACE obejmuje: zespół interdyscyplinarny (IDT), centrum pobytu dziennego dla dorosłych oraz klinikę zdrowia. Zespół IDT wspólnie podejmuje decyzje dotyczące każdej sfery życia pacjenta z uwzględnieniem jego potrzeb zdrowotnych, psychicznych i środowiskowych. Zespół ten ma na celu efektywne rozwiązywanie problemów pacjenta w jak najkrótszym czasie, aby zapobiec ewentualnym powikłaniom czy hospitalizacji. Opinie zespołu oparte na podstawie kompleksowej analizy stanu zdrowia pacjenta i jego środowiska są podstawą do sformułowania diagnozy i indywidualnego planu opieki pacjenta oraz wyboru najlepszych decyzji w celu jego realizacji. Decyzje podejmowane są zespołowo w formie dyskusji i poprzez głosowanie. Uczestników zespołu obowiązują zasady etyki zawodowej z zachowaniem tajemnicy i godności pacjenta $[6,14,15]$. W skład zespołu IDT wchodzą administrator, lekarz-dyrektor medyczny, pielęgniarki zaawansowanej praktyki klinicznej (ANP) pielęgniarki dyplomowane, dietetyk, koordynator opieki domowej, dyrektor centrum dziennego, pracownicy socjalni, fizykoterapeuta, koordynator zajęć rekreacyjnych i terapii zajęciowej oraz przedstawiciel transportu $[6,8,13$ 15]. Dodatkowo do zespołu IDT przynależy przedstawiciel Duchowieństwa, ponieważ program Mercy LIFE of Alabama, ma podłoże katolickie. Zespół IDT w programie Mercy LIFE of Alabama spotyka się codziennie rano w sali konferencyjnej. Sprawy poruszane dotyczą raportów z dyżurów nocnych, odbytych wizyt w szpitalach czy też $\mathrm{w}$ domach opieki długoterminowej. Zespół poddaje obradom bieżące sprawy uczestników wynikające ze zmiany ich dotychczasowej sytuacji zdrowotnej, społecznej czy finansowej. Częstym problem poddawanym dyskusji jest zapewnienie bezpieczeństwa uczestnikom programu, które ma na celu zapobieganie upadkom oraz zbędnym urazom czy hospitalizacji. Propozycje rozwiązań w tej kwestii mogą dotyczyć małych remontów, czy też budowy bezpiecznego podjazdu dla wózków inwalidzkich. Podczas codziennych obrad rozpatruje się prośby pacjentów, które mogą dotyczyć sprzętu ortopedycznego, protez dentystycznych, aparatów słuchowych, czy też innego rodzaju usług typu: sprzątanie, pranie bielizny, itp. Napływające zażalenia, oraz podjęte w ich sprawie decyzje są punktem dziennych obrad zespołu IDT. Program PACE zawiera wytyczne dotyczące rozpatrywania zażaleń i próśb w terminie ściśle określonym przez CMS według Kodeksu Przepisów Federalnych [15]. Cała ta procedura zarządzeń wpływa na ogólną satysfakcję uczestników programu $[15,16]$. Należy zauważyć, że grupowe rozwiązywanie problemów i podejmowanie decyzji ma w sobie wiele pozytywnych walorów. Daje do wyboru uczestnikom zespołu IDT więcej opcji, zwiększa kreatywność decyzji, daje lepszy wynik ekonomiczny, zmniejsza ryzyko błędu i przyczynia się do lepszego wykorzystania czasu. Wszystko to jest bardzo ważne, bowiem PACE nie otrzymuje zwrotów finansowych za usługi świadczone pacjentom. PACE program podejmuje pełną finansową odpowiedzialność za podjęte decyzje i ich ryzyko. Zyski generowane przez organizację są rezultatem dobrze podejmowanych decyzji $[6,8,14]$ Program PACE nie ma obowiązku płacenia za usługi, które nie były zatwierdzone przez zespół IDT, chyba że nagła sytuacja wymaga takiego przedsięwzięcia. PACE model zawiera zespól pracowników odpowiedzialnych za sprawy budżetowe i specjalistów od marketingu [14].

Każdy PACE program zawiera centrum pobytu dziennego, gdzie pacjenci się socjalizują oraz korzystają z terapii rekreacyjnej. W centrum dziennym znajduje się również oddział fizykoterapii i terapii zajęciowej, którego zadaniem jest polepszenie sprawności fizycznej, bezpieczeństwa i funkcjonalności podopiecznych. Według statystyki krajowej każdy uczestnik programu spędza średnio w centrum od 2-3 dni tygodniowo w zależności od jego indywidualnych potrzeb [7]. W programie Mercy LIFE of Alabama średnia liczba dni spędzonych przez pacjenta w centrum wynosi dwa. Pobyt uczestników w centrum pozwala zespołowi na monitorowanie pacjentów $\mathrm{z}$ uwzględnieniem ich potrzeb i wczesnego wychwytywania zmian w stanie ich zdrowia $[13,16]$. Pracownicy programu PACE są zobowiązani do raportowania do klinik spostrzeżonych zmian w stanie zdrowia pacjenta.

Klinika medyczna jest częścią modelu PACE. Pracownicy kliniki medycznej zapewniają profilaktykę i podstawową opiekę medyczną w zakresie leczenia chorób ostrych i przewlekłych. W ramach regulacji CMS, PACE jest zobowiązany do wykonania ścisłe określonej liczby wizyt klinicznych przez lekarza czy ANP w określonym przedziale czasowym [15]. Pacjent musi być konsultowany w klinice na kompleksowym badaniu kwalifikacyjnym w celu oceny i weryfikacji kryteriów przyjęcia do programu PACE zgodnie z regulacjami PACE i zarządzeniami kodeksu CMS. Następnie pacjent ponownie odbywa pierwszą wizytę pokwalifikacyjną i później regularnie co 6 miesięcy na półrocznych i rocznych złożonych badaniach przeglądowych w celu weryfikacji indywidualnego planu opieki i ustalenia potrzeb zdrowotno-opiekuńczych. Częstsze wizyty mogą wystąpić w przypadku sporadycznych chorób oraz nagłych zmian w stanie zdrowia pacjenta $[14,15]$.

PACE posiada kilkanaście mikrobusów dostosowanych do transportu ludzi ze specjalnymi potrzebami i osób niepełnosprawnych. W przypadku konieczności leczenia szpitalnego pacjent jest przewożony do szpitali, z którymi PACE program ma podpisany kontrakt o współpracy. PACE zapewnia transport medyczny na konsultacje, badania specjalistyczne czy hemodializy. Pacjenci przewożeni są do ośrodków i lekarzy specjalistów, z którymi PACE ma zawartą umowę o leczeniu i współpracy $[10,11,13,14]$. PACE zaopatruje się we wszystkie leki z centralnej apteki, która wyłącznie zaopatruje modele PACE.

Umowa przynależnościowa pacjenta do programu PACE jest bezterminowa i nie może być rozwiązana ze względu na pogarszający się jego stan zdrowia psychicznego czy fizycznego. Kontrakt obowiązuje, aż do śmierci, 
chyba że pacjent lub jego prawny opiekun na własne życzenie zechcą się z programu wypisać lub stan zdrowia pacjenta uległ na tyle poprawie, że nie spełnia on kryteriów kwalifikacji do opieki długoterminowej. Kontrakt może ulec zerwaniu ze względów osobistych na życzenie pacjenta lub opiekuna bez ponoszenia żadnej odpowiedzialności finansowej. PACE program może zerwać kontrakt, jeżeli uczestnik nie przestrzega regulaminu lub stanowi zagrożenie dla innych członków programu. Przykładem może tutaj być przyniesienie do centrum broni czy nielegalne nadużywanie narkotyków. Przepisy takiej procedury są określone w regulaminie CMS do spraw funkcjonowania programów PACE [14].

Współczesny program PACE został utworzony dla pacjentów, którzy osiągnęli wiek 55 lat i ze względów zdrowotnych kwalifikują się do życia w domu opieki społecznej, jakkolwiek chcą pozostać jak najdłużej w domu i niezależnie funkcjonować pod nadzorem programu PACE. Uczestnik musi zamieszkiwać w obszarze zaopatrywanym przez program PACE. Stan jego zdrowia, kondycja fizyczna i funkcjonalność przed przyjęciem do programu nie mogą stanowić zagrożenia dla jego życia w środowisku społecznym. Uczestnik programu musi być w stanie żyć bezpiecznie w domu przy pomocy PACE oraz wyrazić zgodę na przestrzeganie zasad regulaminu programu PACE, które są określone przez CMS [6,8-10,14,17].

\section{Procedura kwalifikacji kandydata do programu PACE}

Nowi kandydaci starający się o przyjecie do programu PACE są poddani wstępnej ocenie przez poszczególnych przedstawicieli zespołu IDT. Zespół dokonuje analizy środowiska, stanu zdrowia, historii chorobowej oraz stopnia zaangażowania i możliwości współpracy rodziny w opiece nad pacjentem. Pacjent odbywa wstępne badanie kwalifikacyjne przez lekarza lub ANP. Jego sprawność fizyczna podlega dalszej ocenie w oddziale fizykoterapii. Pracownik socjalny, przedstawiciel opieki domowej i fizykoterapeuta dokonują inspekcji warunków mieszkaniowych pod względem bezpieczeństwa i funkcjonowania pacjenta w domu. Po dokonaniu analizy zespół IDT decyduje, czy pacjent spełnia kwalifikacje przyjęcia do środowiskowej opieki długoterminowej $[14,15]$. Proces kwalifikacji do programu wymaga wypełnienia przez PACE organizacje specjalnej formy ewaluacyjnej wymaganej przez CMS w celu ewaluacji kryteriów przyjęcia do programu i uzyskania płatności za opiekę nad nim $[14,18]$.

\section{Płatność uczestników programu PACE}

Większość uczestników programu PACE kwalifikuje się do Medicare i Medicaid i są zwolnieni ze wszelkich dodatkowych opłat. Osoby, które nie posiadają ubezpieczenia w Medicaid są zobowiązane do uzupełniających opłat $\mathrm{w}$ formie miesięcznej premii do programu PACE według kodu 460.186. [14]. Uczestnicy posiadający wyłącznie Medicaid są zwolnieni od wszelakich opłat [14-19]. Diane Brown, Naczelny Dyrektor Zarządzania Organizacją PACE pod nazwą Mercy LIFE of Alabama, stwierdza, że ponad 99\% uczestników w Mercy LIFE of Alabama, w PACE programie nie ponosi żadnych dodatkowych kosztów za opiekę. Osoby nie posiadające ubezpieczenia moga prywatnie opłacać koszt opieki i należeć do programu, jakkolwiek jest to bardzo rzadkie.

\section{System finansowania programu PACE}

Program ten jest głównie finansowany przez Medicare i Medicaid według ścisłe określonych regulacji CMS $[6,8,14]$. Tradycyjny program Medicare posiada dwa plany: Plan A i Plan B. Plan A pokrywa opiekę instytucjonalną [20]. Medicare plan B pokrywa opiekę ambulatoryjną, psychiatryczną, hemodializy, sprzęt medyczny, oraz niektóre leki [21]. Większość leków, jakkolwiek jest pokrywana w ramach dodatkowego planu $\mathrm{D}$, który jest oferowany przez Medicare w formie opcji płatnej i bezpłatnie w ramach Medicaid. Wszyscy uczestnicy PACE mają obowiązek posiadania planu $\mathrm{D}$, który dla większości naszych pacjentów ze względu na przynależność do obydwu wymienionych programów jest bezpłatny, stwierdza Diane Brown.

PACE program może być dodatkowo sponsorowany przez różne prywatne i społeczne organizacje [17]. CMS, określa zasady i kryteria płatności za opiekę dla programu PACE. Medicare płaci programowi PACE miesięczną, ryczałtową stawkę na każdego pacjenta w zależności od wielkości czynnika ryzyka chorobowego, który jest różny dla każdego pacjenta. Medicaid z kolei wypłaca programowi PACE z góry ustaloną sumę za opiekę, która jest niezależna od ciężkości stanu chorobowego pacjenta. Wysokość tej sumy nie podlega negocjacji, jakkolwiek jej wielkość zależy od stanu, w którym pacjent zamieszkuje $[9,14,19,22]$. Dla przykładu Medicaid w stanie Alabama płaci programowi PACE za każdego pacjenta stałą stawkę miesięczną w wynosi 3330 dolarów, stwierdza Diane Brown.

W roku 2008 został wprowadzony przez CMS model oceny indeksu ryzyka, który ułatwił określenie wielkości miesięcznej opłaty ryczałtowej za świadczoną opiekę zdrowotną dla programu PACE [19]. Na obliczenie wielkości indeksu ryzyka zdrowia mają wpływ czynniki demograficzne, takie jak: wiek, płeć stopień inwalidztwa, czy też rodzaj posiadanego ubezpieczenia społecznego. Inne czynniki to stan zdrowia $\mathrm{z}$ uwzględnieniem rodzaju aktywnych chorób przewlekłych oraz ich klinicznego zaawansowania. W analizie oceny wielkości indeksu ryzyka brane są pod uwagę najbardziej złożone i zaawansowane choroby, a nie ich ilość. Do każdej złożonej choroby określonej w protokole doliczany jest relatywny koszt wydatków w skali roku i relatywny wskaźnik ryzyka ściśle dla tej choroby określany. Na wielkość indeksu ryzyka wpływa również stopień inwalidztwa i upośledzenia funkcjonalności z powodu istnienia tych chorób. Funkcjonalność określa się jako możliwości samodzielnego wykonywania podstawowych czynności życiowych (ADL), do których należą: kąpiel, ubieranie się, korzystanie z toalety, nietrzymanie moczu czy kału, poruszanie się oraz możliwość samodzielnego spożywania posiłków. Ilość zaburzonych funkcji wyraża się w postaci liczbowej od 1-6. Korzystanie z usług opieki domowej z powodu upośledzonej funkcjonalności, używanie sprzętu medycznego, wózków inwalidzkich, tlenu, czy też zaawansowany wiek zwiększa ryzyko zdrowia 
i koszty opieki. Wielkość ryczałtowej wypłaty miesięcznej jaką otrzymuje PACE za pacjenta od CMS zależny od wielkości wskaźnika ryzyka i jest sumą poszczególnych kosztów ściśle określonych według zasad CMS [19] W programie Mercy LIFE of Alabama, średni wiek pacjenta wynosi 80 lat, pacjent ma średnio 7,9 problemów medycznych i jest wspomagany średnio w 3 podstawowych aktywnościach życiowych $[3,23]$. Według wypowiedzi Diane Brown, tylko 4\% uczestników Modelu PACE $\mathrm{w}$ programie Mercy Life of Alabama żyje w domach opieki społecznej, w porównaniu do $7 \%$ w skali krajowej [7].

\section{Zalety programu PACE}

PACE dostarcza wysoką jakość opieki dla ich uczestników. Satysfakcja ogólna uczestników PACE osiąga 72\% w porównaniu do statusu $55 \%$ satysfakcji dla osób żyjących poza programem. Pacjenci w programie PACE dłużej pozostają funkcjonalni w zakresie czynności podstawowych i złożonych w porównaniu z tymi, którzy żyją poza programem $[8,24]$. Dostarczenie transportu do centrum pozwala uczestnikom na niezależność oraz elastyczność w wyborze aktywności. Opieka medyczna jest systematyczna, czego wynikiem jest wydłużenie okresu życia, funkcjonalności i obniżenie zachorowalności. Nakłady finansowe na opiekę zdrowotną uczestnika PACE w ciągu pierwszych 6 miesięcy jego funkcjonowania w programie przedstawiały się następująco: koszty hospitalizacji obniżyły się o 50\%, czas pobytu w szpitalu skrócił się z 6 do 2 dni. Liczba przyjęć do domów opiekuńczych zmniejszyła się o $60 \%$, a długość ich pobytów skróciła się z 22 dni do 7 dni [24]. Badania wykazały, że większość ludzi powyżej 65 lat preferuje stan umierania w domu lub hospicjum. PACE program daje właśnie taką możliwość, jakkolwiek według obecnych statystyk tylko $20 \%$ umiera w domach czy hospicjum. Wciąż 77\% pacjentów umiera w instytucjach, z czego 53\% umiera na oddziałach intensywnej opieki szpitalnej [25].

\section{Ograniczenia programu PACE}

Pomimo wysokiej popularności zapotrzebowania na powyższy model opieki daje się zauważyć, że program ma swoje ograniczenia. W wielu pracach naukowych dokonanych na podstawie przeglądu literatury PACE zostało wykazane, że część uczestników programu woli opiekę we własnych domach i pobyt w centrum dziennym, nie jest dla nich korzystny. Większość podopiecznych spędza średnio w centrum 2-3 dni w tygodniu. Niezadowolenie dotyczy również zmiany dotychczasowego lekarza ogólnego i specjalistów, bowiem program PACE korzysta z własnych lekarzy i szpitali, z którymi posiada kontrakty dla złagodzenia kosztów finansowych. Poza tym PACE jest niedostępny dla obywateli młodszych, poniżej 55 roku życia z zaburzeniami intelektualnymi oraz mniej dostępny dla obywateli średniej klasy, którzy nie kwalifikują się do otrzymywania Medicaid i są zmuszeni do pokrycia z własnych funduszy dodatkowych kosztów za opiekę do programu PACE $[8,10,16,26]$.

\section{Warianty PACE}

W celu przekroczenia powyższych barier kilkanaście programów zaadoptowało różnice $\mathrm{w}$ funkcjonowaniu dając możliwość swoim podopiecznym na utrzymanie dotychczasowego lekarza opieki podstawowej, przychodzenie do centrum dziennego w razie potrzeby lub też rezygnacja $\mathrm{z}$ pobytu $\mathrm{w}$ centrum $\mathrm{i}$ korzystanie $\mathrm{z}$ usług oraz opieki w domu pacjenta [9]. Wyróżnia się kilkanaście wariantów zmodyfikowanych programów PACE, do których należą: Model Geriatric Resourses for Assessment and Care of Elders (GRACE) i Model Wisconsin Partnership Program (WPP) $[8,16,27,28]$. Wszystkie te zmiany mają na celu dalszy rozwój i zwiększanie satysfakcji wśród podopiecznych oraz szerszą dostępność do programów opieki zintegrowanej. Niektóre z tych wariantów ze względu na swoją funkcjonalność znajdują zastosowanie w krajach poza Ameryką [6].

Jak widać jeden model nie jest w stanie zapewnić wszystkich potrzeb starzejącego się społeczeństwa, dlatego podkreśla się konieczność elastyczności w funkcjonowaniu programów w zależności od potrzeb uczestników i udziału rodziny w opiece $[9,16,26]$.

\section{PODSUMOWANIE}

Autor artykułu widzi wiele podobieństw w sprawowaniu opieki nad starzejącymi się członkami rodziny w kulturze swojego kraju, jakim jest Polska. Uważa, że wyżej wymieniony model PACE, czy jego zmodyfikowany wariat byłby idealnym rozwiązaniem opieki pozainstytucjonalnej przy optymalnych nakładach finansowych i dużej satysfakcji ze strony podopiecznych i ich rodzin. Polska podobnie jak Ameryka i inne kraje wysoko uprzemysłowione będzie miała porównywalne problemy demograficznego wzrostu starzejącej się populacji i podobne problemy finansowe związane ze wzrostem kosztów opieki medycznej dla tych, którzy będą jej najbardziej potrzebować. Rosnąca populacja osób starszych wskazuje na bezzwłoczne działanie społeczeństwa w tym zakresie. Program podobny do PACE jest skutecznym rozwiązaniem kompleksowej opieki geriatrycznej i w opinii autora wykracza on w przyszłość ze względu na jego funkcjonalność i ekonomiczność.

\section{PIŚMIENNICTWO/REFERENCES}

1. Carr E. Caring for An Aging Population. Stanford Social Innovation Review, 0ct.21, 2016. Available at https://ssir.org/articles/entry/caring_for_an_aging population. Access: 02.12.2016

2. Ortman JM, Velkoff VA, Hoga H. An Aging Nation: The Older Population in the United States U.S. Department of Commerce Economics and Statistics Administration. Current Population Reports. Issued May 2014, 25-1140.

3. Shear S. Expending the Program of All Inclusive Care for the Elderly in Alabama to Improve care and limit Cost for Frail Adults. (PACE) Addressed to Budget Committee of the Alabama Assembly. 2016.

4. Neuman T, CubanskiJ. The Rising Cost of Living Longer: Analysis of Medicare Spending by Age for Beneficiaries in Traditional Medicare. Jan 14, 2015. Available at http:// $\mathrm{kff}$.org/medicare/report/the-rising-cost-of-living-longer-analysis-of-medicarespending-by-age-for-beneficiaries-in-traditional-medicare. Access: 02.12.2016

5. Center on Budget and Policy Priorities. Basics Introduction to Medicaid, Updated, August 16, 2016. Available at http://www.cbpp.org/research/health/policy-basicsintroduction-to-medicaid. Access: 02.12.2016

6. Casiano A. PACE: A Model of Care for Individuals with Multiple Chronic Conditions." Annals of Long Term Care: Clinical Care and Aging. 2015;23(7):41-45.6 
7. National PACE Association. Is PACE for You? Available at http://www.npaonline.org/ pace-you\#History. Access: 02.12.2016

8. Hirth V, Baskins J, Dever-Bumba M. Program of All-Inclusive Care (PACE):Past, Present, and Future. J. Am Med Dir Assoc. 2009; 10(3):155-160. Available at http:// www.dhcs.ca.gov/provgovpart/Documents/Waiver\%20Renewal/PACE_Article_ JAMDA_091.pdf.

9. Petigara T, Anderson G. Program of All-Inclusive Care for the Elderly. Health Policy Monitor, April 2009. Available at http://www.npaonline.org/sites/default/files/ PDFs/Health\%20Policy\%20Monitor\%20-\%202009.pdf.

10. Center for Medicare and Medicaid Services. Quick Facts About Programs of Allinclusive Care for the Elderly (PACE) January 2008 Available at https://www.cms. gov/Medicare/Health-Plans/pace/downloads/externalfactsheet.pdf

11. National PACE Association. Understanding PACE Program All-Inclusive Care for the Elderly Available at http://www.npaonline.org/sites/default/files/PDFs/3\%20 PACE\%20Fact\%20Sheet\%20DRAFT\%201.pdf.

12. PACE Programs, a Budding Solution for Extended Care, Threatened by Proposed Budget. Alabama Media Group Marketing Staff March 17, 2016. Available at http:// blog.al.com/sponsored/2016/03/pace_programs_a_budding_soluti.htm. Access: 02.12.2016

13. National PACE Association. Understanding PACE. A Profile of PACE. Available at http://www.npaonline.org/sites/default/files/PDFs/7\%20Profile $\% 20$ of $\% 20$ PACE\%20DRAFT\%201.pdf.

14. Code of Federal Regulation. Available at http://pace.techriver.net/website/ download.asp?id=2520\&title=PACE_Regulations-Final_and_Interim_-_as_ of_5/31/13. Access: 02.12.2016

15. CMS: Programs of All Inclusive Care for the Elderly (PACE) Regulation and Guidance Chapter 8IDT, Assessment \& Care Planning https://www.cms.gov/Regulations-andGuidance/Guidance/Manuals/downloads/pace111c08.pdf.

16. Retooling for an Aging America: Building the Health Care Workforce. New Models of Care Chapter: 3, 2008. Available at https://www.nap.edu/read/12089/ chapter/5\#118. Access: 02.12.2016

17. National PACE Association. PACE in Your Community: Understanding PACE Operating Experience and the Critical Success Factors. March, 2013 Available at http://www. npaonline.org/sites/default/files/PDFs/PACE\%20Critical20Success\%20Factors\%20 White\%20Paper.pdf.

18. Alabama Medicaid Agency. Admission and Evaluation Assessment Tool for PACE. Form:12-001 September, 2012 Available at http://www.smartbudgeting.alabama. gov/documents/5.0_Resources/5.4_Forms_Library/5.4.3_LTC_Services/5.4.3_ PACE_Assessment_Form_12-001_9-14-12.pdf.

19. Pope $G$, Kautter 0 , Ingber M, Freeman S, et al. Evaluation of the CMS-HCC Risk adjustment model. Final Report RTI Project Number 0209853.006 Available at https://www.cms.gov/Medicare/HealthPlans/MedicareAdvtgSpecRateStats/ Downloads/Evaluation_Risk_Adj_Model_2011.pdf.

20. Mecicare.gov What Part A Covers? Available at https://www.medicare.gov/whatmedicare-covers/part-a/what-part-a-covers.html. Access: 02.12.2016

\section{Nota o Autorze}

Autorka jest absolwentką Wydziału Pielęgniarskiego Akademii Medycznej w Lublinie, studiowała w latach 1987-1992. W latach 1995-2010 pracowała zawodowo na terenie USA w charakterze pielęgniarski dyplomowanej na oddziałach: geriatrii, chirurgii i izbie przyjęć. W roku 2008 uzyskała specjalizację pielęgniarską w medycynie nagłych przypadków (Board Certified Emergency Nurse). W roku 2013 ukończyła dwuletnie studia podyplomowe na Wydziale Pielęgniarskim Uniwersytetu Południowej Alabamy w Mobile i uzyskała kwalifikacje oraz uprawnienia zawodowe w zakresie pieleggniarstwa zaawansowanej praktyki (ANP- Advanced Nurse Practitioner) w dziedzinie dorosłych i geriatrii w zakresie opieki ambulatoryjnej (Adult-Gerontology Nurse Practitioner Primary Care, Board Certified AGNP-PC, BC). Aktualnie autorka artykułu pracuje w organizacji PACE (Program of All-Inclusive Care for the Elderly) jako klinicznie zaawansowana pielęgniarka (ANP). Jest to katolicka instytucja o
21. Mecicare.gov What Part B covers? Available at https://www.medicare.gov/whatmedicare-covers/part-b/what-medicare-part-b-covers.html. Access: 02.12.2016

22. PACE and Medicare Risk Adjustment. Available at http://pace.techriver.net/website/ article.asp?id=808. Access: 02.12.2016

23. PACE Programs Allow Elderly to Live at Home Longer and Save the State Money. Mercy LIFE Alabama, Media Group July 26, 2016 Available at http://blog.al.com/ sponsored/2016/07/pace_programs_allow_elderly_to.html. Access: 02.12.2016

24. Evaluation of the Program of All-Inclusive Care for the Elderly (PACE) Demonstration: The Impact of PACE on Participant Outcomes Final Report for HCFA Contract \#50096-0003/T04. July,1998. Available at https://www.npaonline.org/sites/default/ files/PDFs/Impact\%20of\%20PACE\%20on\%20Participant\%200utcomes.pdf.

25. Temkin-Greener H, Mukamel D. Predicting Place of Death in the Program of AllInclusive Care for the Elderly (PACE): Participant versus Program Characteristics. Journal of the American Geriatrics Society 2002; 50: 125-135. doi:10.1046/j.15325415.2002.50018.x.

26. Lynch M, Hernendez M, Estes C. PACE Has it Change the Chronic Care Paradigm? Social Work in Public Health. 2008; 23 (4): 3-23.

27. Counsell SR, Callahan CM, Buttar AB,Frank Kl, Geriatric Resources for Assessment and Care of Elders (GRACE) Model: A New Model for Primary Care for Low Income Seniors J AM Geriatric Soc. 2006; 54(7):1136-1141.

28. Kane RL, Homyac P, Bershadsky B. Consumer Reactions to the Wisconsin Partnership Program and Its Parent, the Program for All-Inclusive Care of the Elderly (PACE) The Gerontologist. 2002; 42 (3): 314-320.

Praca przyjęta do druku/Manuscript received: 08.12.2016

Praca zaakceptowana do druku/Manuscript accepted: 30.01.2017

\section{Ministerstwo Nauki \\ i Szkolnictwa Wyższego}

„Konsultacje z zagranicznymi naukowcami i wprowadzenie dwujęzycznych (j. polski/angielski) treści do czasopisma Pielęgniarstwo XXI wieku" finansowane w ramach umowy 547/P-DUN/2016 ze środków Ministra Nauki i Szkolnictwa Wyższego przeznaczonych na działalność upowszechniającą naukę.

nazwie Mercy LIFE of Alabama (Living Independently For Elders), co oznacza Życie Niezależne Dla Seniorów. Funkcje zawodowe autora w systemie PACE obejmują dostarczanie podstawowej opieki zdrowotnej dla pacjentów i orzekanie w kwestiach dotyczących ich zdrowia.

\section{Podziękowanie}

Barbara Ślusarska, Dr hab. n. o zdr. Zakład Medycyny Rodzinnej i Pielęgniarstwa Środowiskowego, Wydział Nauk o Zdrowiu, Uniwersytet Medyczny, w Lublinie - za twórczą inspirację w przygotowaniu opracowania.

Diane Brown, RN, BSEd. Naczelny Dyrektor Zarządzania Organizacją PACE pod nazwą Mercy LIFE of Alabama, Mobile, USA - za konsultacje dotyczące funkcjonowania organizacji PACE, Mercy LIFE of Alabama.

\section{Oświadczenie}

Autor oświadcza, że nie otrzymał żadnych finansowych gratyfikacji za powyższy manuskrypt od Mercy LIFE of Alabama, PACE organizacji. 


\section{Biographial Note}

The author completed her studies at the Faculty of Nursing and Health Sciences at the Medical University of Lublin from 1987 to 1992. In 2013, she completed her 2-year postgraduate studies at the College of Nursing at the University of South Alabama in order to receive her qualifications and license to practice as an Advanced Nurse Practitioner in the field of Adult Gerontology Primary Care. Between the years 1995 and 2010, the author worked in the United States in the departments of gerontology, surgery, and emergency medicine. In 2008, she obtained Board Certification in Emergency Nursing.

The author works at a Catholic institution named Mercy LIFE (Living Independently for Elders) PACE program in Mobile, Alabama, as an Advanced Nurse Practitioner (ANP). The author's functions in the PACE system include exercising primary patient care and providing medical advice on issues relating to the health of patients.

\section{Acknowledgements}

Barbara Ślusarska, Ph.D. at the Department of Family Medicine and Community Nursing at the Faculty of Health Sciences at the Medical University of Lublin - for inspiration in preparing this article.

Diane Brown, RN, BSEd. Executive Director at Mercy LIFE of Alabama - for consultation in regards to the functioning of the PACE program at Mercy LIFE of Alabama.

\section{Disclosure}

Author is an employee of Mercy LIFE organization. No financial support for this manuscript was provided to the author by Mercy LIFE. 